\title{
simpleGAMMA v1.0 - a reduced model of secondary organic aerosol formation in the aqueous aerosol phase (aaSOA)
}

\author{
J. L. Woo and V. F. McNeill \\ Department of Chemical Engineering, Columbia University, New York, NY 10027, USA \\ Correspondence to: V. F. McNeill (vfm2103@columbia.edu)
}

Received: 05 December 2014 - Published in Geosci. Model Dev. Discuss.: 22 January 2015

Revised: 19 May 2015 - Accepted: 01 June 2015 - Published: 22 June 2015

\begin{abstract}
There is increasing evidence that the uptake and aqueous processing of water-soluble volatile organic compounds (VOCs) by wet aerosols or cloud droplets is an important source of secondary organic aerosol (SOA). We recently developed GAMMA (Gas-Aerosol Model for Mechanism Analysis), a zero-dimensional kinetic model that couples gas-phase and detailed aqueous-phase atmospheric chemistry for speciated prediction of SOA and organosulfate formation in cloud water or aqueous aerosols. Results from GAMMA simulations of SOA formation in aerosol water (aaSOA) (McNeill et al., 2012) indicate that it is dominated by two pathways: isoprene epoxydiol (IEPOX) uptake followed by ring-opening chemistry (under low- $\mathrm{NO}_{x}$ conditions) and glyoxal uptake. This suggested that it is possible to model the majority of aaSOA mass using a highly simplified reaction scheme. We have therefore developed a reduced version of GAMMA, simpleGAMMA. Close agreement in predicted aaSOA mass is observed between simpleGAMMA and GAMMA under all conditions tested (between $\mathrm{pH}$ 1-4 and $\mathrm{RH} 40-80 \%$ ) after $12 \mathrm{~h}$ of simulation. simpleGAMMA is computationally efficient and suitable for coupling with larger-scale atmospheric chemistry models or analyzing ambient measurement data.
\end{abstract}

\section{Introduction}

Quantifying the sources of tropospheric aerosol material is important for accurate modeling of air quality and climate. In situ processes leading to the formation of new organic aerosol material, collectively known as secondary organic aerosol (SOA) formation, are poorly constrained in atmospheric chemistry models (Kanakidou et al., 2005; Hallquist et al., 2009; Hodzic et al., 2010). Disagreement between model results and observations of the quantity, degree of oxidation, and location of organic aerosols in the atmosphere has suggested an incomplete representation of SOA formation pathways in models (Heald et al., 2005; Jimenez et al., 2009). In the past decade, the uptake of water-soluble volatile organic compounds (VOCs) into cloud droplets or aerosol water, followed by aqueous-phase chemical processing, has received increased attention as a possibly important source of SOA (Blando and Turpin, 2000; Ervens et al., 2011). It is thought to be especially significant in the case of isoprenederived SOA formation. This is because most of the gasphase oxidation products of isoprene, are, like isoprene itself, highly volatile; however, some, like glyoxal (GLYX), isoprene-derived epoxydiols (IEPOX) (Paulot et al., 2009; Surratt et al., 2010) and methacrylic acid epoxide (MAE) (Lin et al., 2013), are water-soluble. These species also undergo reactive processing in the aqueous phase of cloud droplets or aerosols, increasing their uptake from the gas phase.

Despite mounting evidence that aqueous atmospheric chemistry is a significant source of SOA, aqueous aerosol and cloud water SOA formation is not yet widely represented in 3-D atmospheric chemistry and air quality models. This is due, in part, to the challenges of bridging scales between the detailed information generated by laboratory experiments and simplified representations suitable for implementation in 3-D models, which can afford to carry relatively few chemical tracers. Including cloud-water organic chemistry in largescale atmospheric chemistry models has improved agreement with observations (Carlton et al., 2008; Myriokefalitakis et al., 2011; Liu et al., 2012), but aqueous aerosol processes are 
just beginning to be represented (Pye et al., 2013; Knote et al., 2014; Lin et al., 2014).

Previously, we developed GAMMA (Gas-Aerosol Model for Mechanism Analysis), a zero-dimensional kinetic model that couples gas- and detailed aqueous aerosol-phase chemistry for speciated prediction of SOA and organosulfate formation in the aqueous aerosol phase under ambient or laboratory conditions (McNeill et al., 2012; Woo et al., 2013). GAMMA represents aaSOA (SOA formation in aerosol water formation in terms of aqueous uptake followed by aqueous-phase reaction (Schwartz, 1986). GAMMA includes IEPOX chemistry following Eddingsaas et al. (2010) and uses effective Henry's law constant, $H^{*}$, constrained by aerosol chamber studies (Sumner et al., 2014) to describe glyoxal uptake and dark reactions, as well as detailed photochemical organosulfate formation and brown carbon formation from glyoxal, methylglyoxal, and acetaldehyde (Woo et al., 2013). For more information regarding other specific mechanisms included in GAMMA, as well as rate constants for these reactions and other physical parameters, the reader is referred to McNeill et al. (2012) (including the Supplement) and Woo et al. (2013).

Simulations using GAMMA indicate that the IEPOX pathway dominates aaSOA formation, leading to up to $\sim 0.9 \mu \mathrm{g} \mathrm{m}^{-3}$ of SOA mass under conditions typical of the rural SE USA (McNeill et al., 2012). Pye et al. (2013) predicted similar mean concentrations $\left(0.6-1.0 \mu \mathrm{g} \mathrm{m}^{-3}\right)$ of IEPOX-derived SOA mass for the SE USA in summer 2006, using CMAQ (Community Multiscale Air Quality model) with a surface reactive uptake formulation of IEPOX aaSOA formation. In urban (high- $\mathrm{NO}_{x}$ ) environments, aaSOA is primarily formed via glyoxal uptake (McNeill et al., 2012).

This predominance of two aaSOA formation pathways involving relatively few species, compared to the total number of aqueous compounds tracked by GAMMA, suggests that it is possible to model the majority of aqueous aerosolphase SOA mass using a highly simplified reaction scheme, which is computationally efficient and suitable for coupling with larger-scale atmospheric chemistry models. GAMMA has therefore been used as a guide to develop a reduced mechanism for aaSOA formation, simpleGAMMA. simpleGAMMA reduces the total number of tracked aqueous species from 140 to 4 (glyoxal, IEPOX, 2-methyltetrol, and IEPOX organosulfate), with 2 species partitioning between the gas and aqueous aerosol phases (glyoxal and IEPOX), and a single aqueous-phase chemical process (reactive uptake of IEPOX), compared to 118 in GAMMA.

\section{2 simpleGAMMA: model description}

As in GAMMA, the time evolution of the aqueous aerosolphase concentration $\left(C_{i}\right.$, in mol $\left.\mathrm{L}^{-1}\right)$ of a given chemical species $i$ is described in simpleGAMMA by the following differential equation (Schwartz, 1986):

$\frac{\mathrm{d} C_{i}}{\mathrm{~d} t}=\frac{k_{\mathrm{mt}, i}}{R T} P_{i}-\frac{k_{\mathrm{mt}, i}}{H_{i}^{*} R T} C_{i}+\sum_{k} r_{i k, \mathrm{aq}}$.

Here, $P_{i}$ is the gas-phase partial pressure of species $i, H_{i}^{*}$ is effective Henry's law constant, $R$ is the universal gas constant, and $T$ is temperature. The rates $r_{i k \text {,aq }}$ represent chemical reactions in the aerosol phase that can act as sources or sinks for a given species. $k_{\mathrm{mt}, i}$ is the gas-aerosol mass transfer coefficient for species $i$, given by

$k_{\mathrm{mt}, i}=\frac{1}{\frac{R^{2}}{3 D_{\mathrm{g}, i}}+\frac{4 R}{3 \omega_{i} \alpha_{i}}}$,

where $R$ is the aerosol particle radius, $D_{\mathrm{g}, i}$ is the gas-phase diffusion coefficient, $\omega_{i}$ is the thermal velocity, and $\alpha_{i}$ is the accommodation coefficient. A suitable gas-phase chemical mechanism should be employed, and the loss or gain of species to/from the aerosol phase should be accounted for following, for example,

$$
\frac{\mathrm{d} P_{i}}{\mathrm{~d} t}=-k_{\mathrm{mt}, i} a_{\mathrm{L}} P_{i}+\frac{k_{\mathrm{mt}, i} a_{\mathrm{L}}}{H_{i}^{*}} C_{i}+\sum_{j} r_{i j, \mathrm{gas}}+E_{i}-D_{i},
$$

where $a_{\mathrm{L}}$ is the aerosol aqueous liquid volume fraction $\left(\mathrm{cm}^{3} \mathrm{~cm}^{-3}\right.$ of air), $r_{i j, \text { gas }}$ is the rate of gas-phase reaction $j$ that species $i$ participates in, and $E_{i}$ and $D_{i}$ are the emission and deposition rates of species $i$, respectively.

Note that simpleGAMMA is a reduced version of the aqueous-phase mechanism of GAMMA (McNeill et al., 2012). The gas-phase mechanism of GAMMA was not changed because it is intended that simpleGAMMA take gas-phase concentration fields as inputs from an external source, i.e., from field measurements or from existing models of atmospheric chemistry, which have gas-phase chemical mechanisms but lack representations of aqueous aerosol-phase SOA formation. For tests reported here, we ran simpleGAMMA with the full gas-phase mechanism of GAMMA, following Eqs. (1)-(3). A full description of the gas- and aqueous-phase mechanisms of GAMMA, the simulation conditions, and results can be found in McNeill et al. (2012).

The processes leading to aaSOA formation in simpleGAMMA are a subset of those represented in GAMMA and they were selected with the goal of minimizing the number of aqueous-phase tracers and species being exchanged between the gas and aerosol phases, while maximizing the aaSOA mass captured compared to that as predicted by GAMMA after $12 \mathrm{~h}$ of simulated chemistry, assuming no initial aerosol-phase organic mass. The detailed comparison of GAMMA and simpleGAMMA output under a range of typical environmentally relevant conditions can be found in the following section. The aqueous-phase species tracked in simpleGAMMA are IEPOX, glyoxal, 2-methyltetrol, and IEPOX organosulfate. Mass transfer between the gas and 
Table 1. Gas-aerosol mass transfer parameters in simpleGAMMA.

\begin{tabular}{|c|c|c|c|}
\hline Species & $\begin{array}{l}\text { Effective } \\
\text { Henry's law } \\
\text { constant, } H^{*} \\
\left(\mathrm{M} \mathrm{atm}^{-1}\right)\end{array}$ & $\begin{array}{l}\text { Accommodation } \\
\text { coefficient, } \alpha\end{array}$ & References \\
\hline IEPOX & $3 \times 10^{7}$ & 0.02 & $\begin{array}{l}\text { McNeill et al. (2012), } \\
\text { Nguyen et al. (2014) }\end{array}$ \\
\hline GLYX & $2.7 \times 10^{7}$ & 0.023 & $\begin{array}{l}\text { Herrmann et al. (2005), } \\
\text { Sumner et al. (2014) }\end{array}$ \\
\hline
\end{tabular}

aerosol phases only occurs for IEPOX and glyoxal. The effective Henry's law constants $\left(H^{*}\right)$ and accommodation coefficients used to describe uptake for these species are given in Table 1. These $H^{*}$ values have been updated based on advances in the literature since McNeill et al. (2012), and they represent our best understanding of the valid parameters for deliquesced aerosols. They are not valid for non-aqueous aerosols. The values, especially $H^{*}$ for IEPOX (Budisulistiorini et al., 2015), have significant uncertainty associated with them, largely because relatively few experimental studies of $H^{*}$ for uptake of these species to deliquesced aerosols are available in the literature (Kampf et al., 2013; Gaston et al., 2014; Nguyen et al., 2014).

We note that, subsequent to the publication of McNeill et al. (2012), the gas- and aqueous-phase chemistry of MAE was introduced to the full version of GAMMA following Lin et al. (2013). The predicted contribution of this pathway to aaSOA was minor compared to IEPOX and glyoxal, consistent with the findings of Pye et al. (2013). Therefore, it is not included in simpleGAMMA.

Reversible hydration and oligomerization chemistry of glyoxal in the aqueous phase (Whipple, 1970) is captured using the effective Henry's law constant, $H^{*}$ (Schwartz, 1986). Therefore, those processes are not represented explicitly in either GAMMA or simpleGAMMA, in order to avoid double counting. The aqueous processing of IEPOX to form 2methyltetrols (tetrol) and IEPOX organosulfate (IEPOXOS) is represented as one reactive process following a simplified version of the mechanism of Eddingsaas et al. (2010):

$\operatorname{IEPOX}(\mathrm{aq}) \rightarrow(1-\beta)$ tetrol $+\beta$ IEPOXOS.

Here, we apply a value for the branching ratio, $\beta$, of 0.4 , which is an estimate based on the measurements of Eddingsaas and coworkers for the most concentrated bulk solution they studied. The rate constant for the reaction, $k_{1}$, is a function of proton activity and nucleophile concentrations, again following Eddingsaas et al. (2010). We have modified the formula to include the possible protonation of IEPOX (aq) by ammonium as observed by Nguyen et al. (2014).

$$
\begin{aligned}
k_{1} & =\left(\frac{\left[\mathrm{H}_{2} \mathrm{O}\right]}{55.1}\right) k_{\mathrm{H}^{+}} a_{\mathrm{H}^{+}}+k_{\mathrm{SO}_{4}^{2-}}\left[\mathrm{SO}_{4}^{2-}\right] a_{\mathrm{H}^{+}} \\
& +k_{\mathrm{HSO}_{4}^{-}}\left[\mathrm{HSO}_{4}^{-}\right]+k_{\mathrm{NH}_{4}^{+}}\left[\mathrm{NH}_{4}^{+}\right]
\end{aligned}
$$

Here, $a_{\mathrm{H}^{+}}$is the $\mathrm{H}^{+}$activity, $k_{\mathrm{H}^{+}}=5 \times 10^{-2} \mathrm{~s}^{-1}, k_{\mathrm{SO}_{4}^{2-}}=$ $2 \times 10^{-4} \mathrm{M}^{-1} \mathrm{~s}^{-1}$, and $k_{\mathrm{HSO}_{4}^{-}}=7.3 \times 10^{-4} \mathrm{M}^{-1} \mathrm{~s}^{-1}$. The ammonium rate constant, $k_{\mathrm{NH}_{4}^{+}}$, was calculated using GAMMA and the results of the chamber study of Nguyen et al. (2014) to be $1.7 \times 10^{-5} \mathrm{M}^{-1} \mathrm{~s}^{-1}$. The rate constant term $k_{\mathrm{H}^{+}}$from Eddingsaas et al. (2010) has been scaled to account for variable water concentrations within the seed aerosol at different $\mathrm{pH}$ and $\mathrm{RH}$ (relative humidity) conditions, consistent with recent literature (Piletic et al., 2013; Pye et al., 2013). The architecture of the simpleGAMMA program is similar to that of GAMMA (McNeill et al., 2012). simpleGAMMA and GAMMA were originally written in MATLAB (MathWorks, Inc.), utilizing the stiff initial value ordinary differential equation solver ode $15 \mathrm{~s} . \mathrm{m}$, but simpleGAMMA is also available in Fortran. Required input parameters for simpleGAMMA are gas-phase concentration fields for IEPOX and glyoxal, aerosol $\mathrm{pH}$, aerosol size distribution or volume-weighted average aerosol diameter, aerosol liquid water content, and aerosol sulfate and bisulfate concentrations. The test simulations in this study were for the same conditions as the high- $\mathrm{NO}_{x}$ and low- $\mathrm{NO}_{x}$ scenarios in McNeill et al. (2012), with one exception: for the low- $\mathrm{NO}_{x}$ simulation, the initial gas-phase mixing ratio of IEPOX is assumed to be $780 \mathrm{ppt}$, instead of zero. This was the steady state value after three simulated day-night cycles in GAMMA, in the absence of aerosol uptake. In all other simulations, the seed aerosols were assumed to be initially composed solely of deliquesced ammonium sulfate, following the size distribution of Whitby (1978), with aerosol loadings of $4.0 \mu \mathrm{g} \mathrm{m}^{-3}$ (rural conditions, following Tanner et al., 2009) or $20 \mu \mathrm{g} \mathrm{m}^{-3}$ (urban conditions, following Jimenez et al., 2003). Initial inorganic aerosol composition was determined by E-AIM (Extended-AIM) outputs for the defined initial $\mathrm{pH}$ and $\mathrm{RH}$ values.

\section{Results}

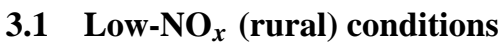

Similar to what was observed in McNeill et al. (2012), under simulated rural (low- $\mathrm{NO}_{x}$ ) environments, both GAMMA and simpleGAMMA predict that aaSOA is dominated by IEPOX and its aerosol-phase reaction products. The evolution of aaSOA mass as predicted over $12 \mathrm{~h}$ of dawn-to-dusk simulation under low- $\mathrm{NO}_{x}$ conditions using GAMMA and simpleGAMMA is shown in Fig. 1 (for aerosol $\mathrm{pH}=1$ and $45 \% \mathrm{RH})$. The pie charts compare the aaSOA composition predicted by both models at $3,6,9$, and $12 \mathrm{~h}$ of simulation. 


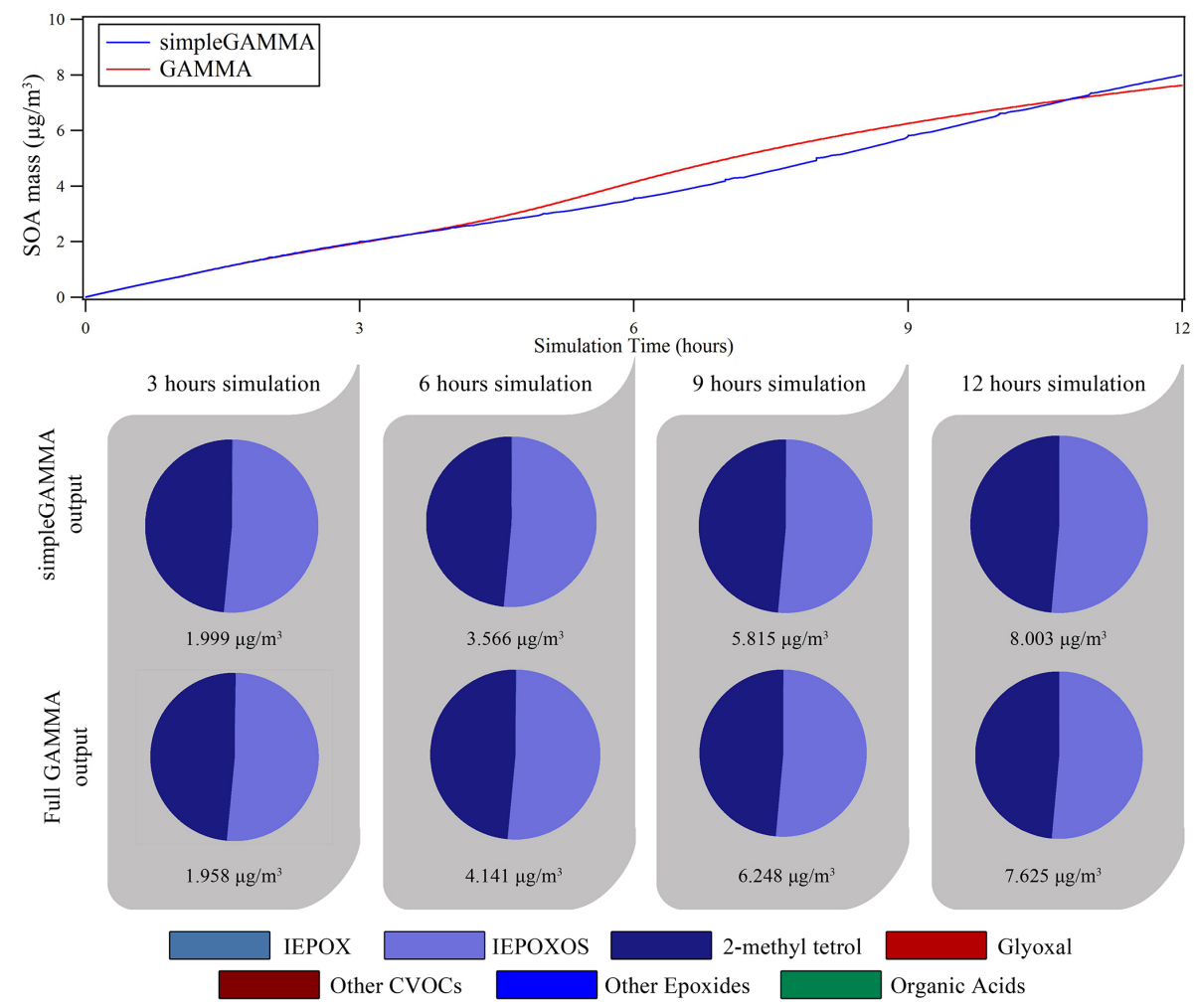

Figure 1. Comparison of simpleGAMMA and GAMMA under low- $\mathrm{NO}_{x}$ conditions, $\mathrm{pH} 1, \mathrm{RH} 45 \%$.

Close agreement in predicted aaSOA mass and its composition can be seen between the two models. Small differences arise due to the fact that, although identical gas-phase mechanisms and initial conditions were used in this model intercomparison, the gas-phase chemistry, especially gas-phase $\mathrm{OH}$, is perturbed by the differences in gas-aerosol mass transfer between the two models. Specifically, VOCs which may partition into the particle phase in GAMMA but not simpleGAMMA are present in the gas phase in higher concentrations in simpleGAMMA, creating an increased sink for $\mathrm{OH}$.

Figure 2 shows the total aaSOA mass predicted by GAMMA and simpleGAMMA for $12 \mathrm{~h}$ of simulation under low- $\mathrm{NO}_{x}$ conditions, with varying aerosol $\mathrm{pH}$ and $\mathrm{RH}$. Like GAMMA, simpleGAMMA predicts maximum aaSOA formation under low- $\mathrm{NO}_{x}$ conditions when aerosol $\mathrm{pH}$ is low and RH is low (but not so low as to cause aerosol efflorescence). This is because in-particle processing of IEPOX is initiated by protonation, so conditions which maximize the in-particle proton concentration yield the highest IEPOX processing. Close agreement (to within $30 \%$ ) exists between aaSOA mass predicted by GAMMA and by simpleGAMMA for $\mathrm{pH} 1$, and within $0.02 \mu \mathrm{g} \mathrm{m}^{-3}$ for aerosol $\mathrm{pH} \geq 2.0$. The highly efficient in-particle IEPOX chemistry at low $\mathrm{pH}$ leads to larger discrepancies between the two models.

\subsection{High-NO ${ }_{x}$ (urban) conditions}

aaSOA mass as predicted by GAMMA is dominated by "dark" uptake of glyoxal under high- $\mathrm{NO}_{x}$ conditions (McNeill et al., 2012). Gas-phase IEPOX formation is expected to be minor in this regime (Paulot et al., 2009). A comparison of evolved aaSOA mass and composition under high-NOx conditions as predicted by GAMMA and simpleGAMMA can be seen in Fig. 3. Figure 4 shows total aaSOA mass predicted by the two models after $12 \mathrm{~h}$ of simulation under highNOx conditions, with varying aerosol $\mathrm{pH}$ and $\mathrm{RH}$. Close agreement (within $0.01 \mu \mathrm{g} \mathrm{m}^{-3}$ ) in predicted total aaSOA mass exists between simpleGAMMA and GAMMA for all relative humidity and $\mathrm{pH}$ values tested. Like GAMMA, under high- $\mathrm{NO}_{x}$ conditions simpleGAMMA predicts increasing aaSOA formation with increasing $\mathrm{RH}$ (and therefore increasing aerosol liquid water content), and no $\mathrm{pH}$ dependence, consistent with glyoxal dark uptake being the dominant aaSOA formation mechanism (Kroll et al., 2005; Galloway et al., 2009; Volkamer et al., 2009). The increased uptake at higher RH amplifies small differences in gas-phase chemistry between simpleGAMMA and GAMMA, due to differing gas-phase $\mathrm{OH}$ sinks in the two models, as described above. GAMMA predicts some contribution to aaSOA mass by photochemical production of succinic acid (see Fig. 3), which is not included in simpleGAMMA. However, since glyoxal is the dominant precursor for succinic acid forma- 

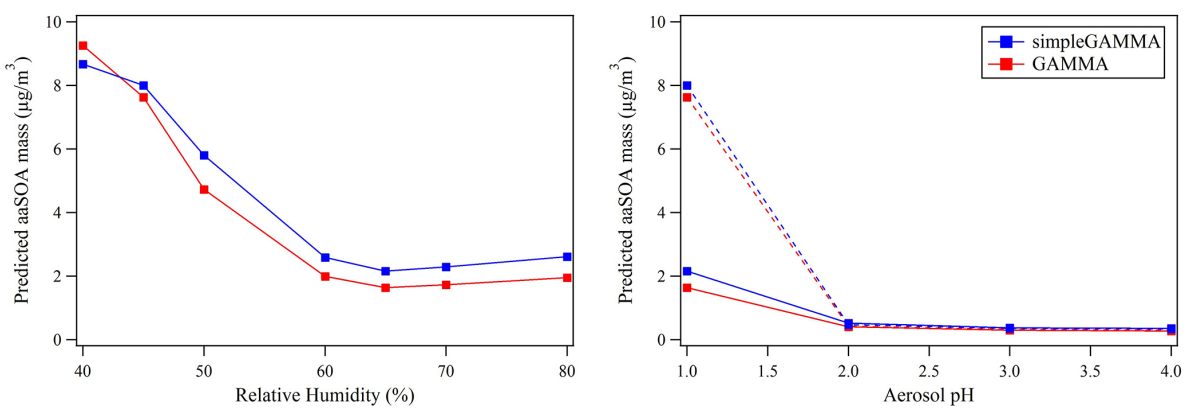

Figure 2. Comparison of predicted aaSOA after $12 \mathrm{~h}$ of simulated time with respect to $\mathrm{RH}$ at $\mathrm{pH} 1$ (left) and with respect to $\mathrm{pH}$ at $45 \%$ and $65 \% \mathrm{RH}$ (right, dotted and solid lines respectively), low- $\mathrm{NO}_{x}$ conditions.

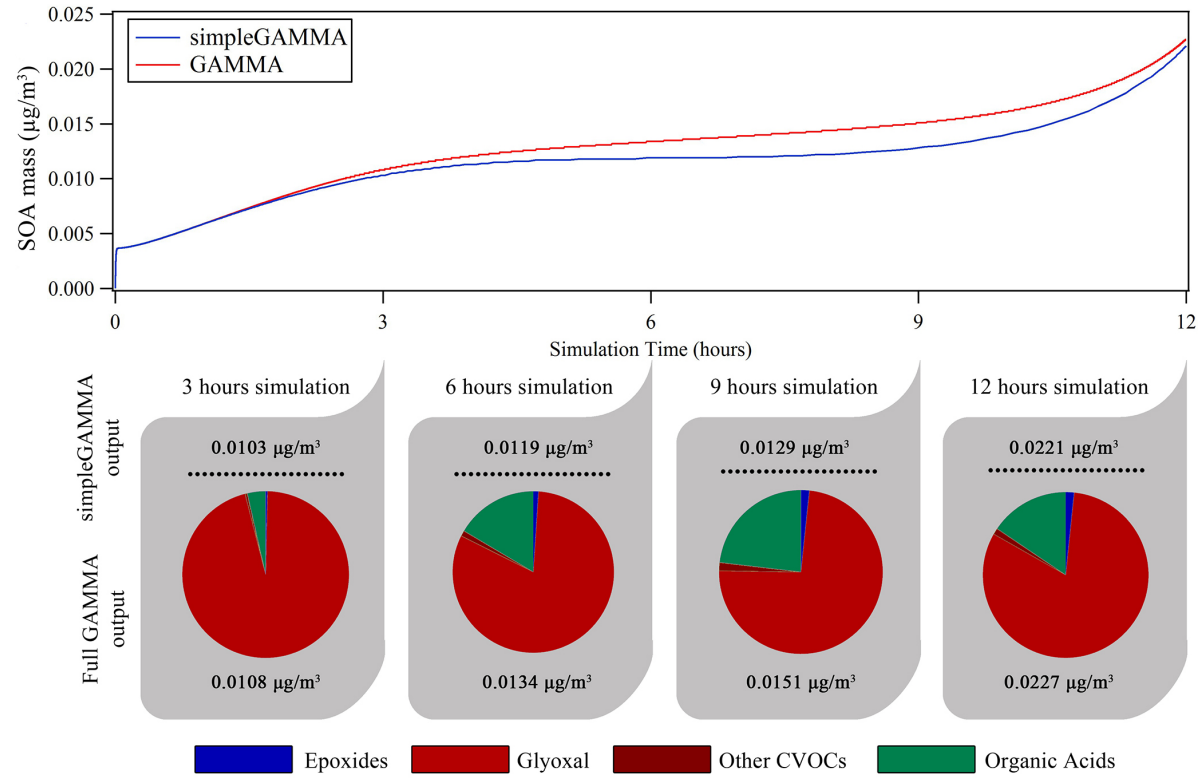

Figure 3. Comparison of high- $\mathrm{NO}_{x}$ simpleGAMMA and the full high- $\mathrm{NO}_{x}$ GAMMA, pH $1, \mathrm{RH} 45 \%$.

tion and the molecular weight of succinic acid $\left(118 \mathrm{~g} \mathrm{~mol}^{-1}\right)$ is comparable to the molecular weight of the two glyoxal molecules that comprise it $\left(116 \mathrm{~g} \mathrm{~mol}^{-1}\right)$, the predicted overall aaSOA mass is therefore very similar for the two models.

\subsection{Computational performance}

The goal of simpleGAMMA is to faithfully represent aaSOA formation with a low number of tracers, in order to simplify the implementation of aqueous aerosol SOA formation in 3-D models (by coupling the gas-phase schemes of those models with simpleGAMMA). However, simpleGAMMA is also computationally faster than GAMMA when run as a box model, as described in this study, due to the reduced number of tracers and reactions in the aqueous phase (recall that the gas-phase mechanisms of GAMMA and simpleGAMMA were identical for the purposes of this study). In $10 \mathrm{sim}$ ulations with starting aerosol $\mathrm{pH} 1$ and $65 \%$ ambient $\mathrm{RH}$, computational run-time for simpleGAMMA under low- $\mathrm{NO}_{x}$ conditions spanned between 10 and $12 \mathrm{~s}$ for $12 \mathrm{~h}$ of simulation, compared to 33-42 s for GAMMA. These runs were performed on an Intel Core i7-3520M CPU in a $2.90 \mathrm{GHz}$ PC, using MATLAB R2014b with the solver ode15s.m Time steps to completion between simpleGAMMA and GAMMA were comparable $(\sim 11000$ and $\sim 14000$ respectively) (indicating similar stiffness in the two models) but simpleGAMMA necessarily utilized less memory cache due to the smaller number of aqueous-phase species and reactions.

\section{Discussion and outlook}

The agreement between GAMMA and simpleGAMMA indicate that this reduced framework can be useful to represent aaSOA mass formation over a variety of relevant ambient conditions. Coupling of simpleGAMMA with regional and global scale 3-D atmospheric chemistry models (Jathar et al., 

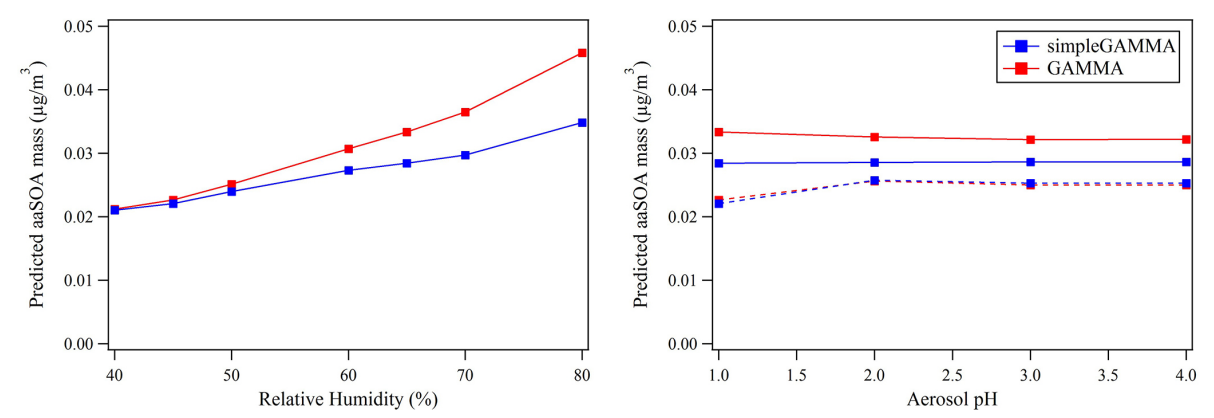

Figure 4. Comparison of predicted aaSOA after $12 \mathrm{~h}$ of simulated time with respect to $\mathrm{RH}$ at $\mathrm{pH} 1$ (left) and with respect to $\mathrm{pH}$ at $45 \%$ and $65 \%$ RH (right, dotted and solid lines respectively), high- $\mathrm{NO}_{x}$ conditions.

2014) and its application to analysis of ambient measurement data (Budisulistiorini et al., 2015) is currently underway.

While we have demonstrated good agreement between simpleGAMMA and GAMMA, the limitations of GAMMA also apply to simpleGAMMA; for example, neither model includes a treatment of oxidative aging of aaSOA at this time due to a lack of kinetic and mechanistic data. As a result, overprediction of total aaSOA mass is likely (Budisulistiorini et al., 2015). The only sources of aqueous-phase $\mathrm{OH}$ in GAMMA are $\mathrm{HOOH}$ photolysis or Henry's law transfer of $\mathrm{OH}$ from the gas phase. Therefore, we, like others (Waxman et al., 2013; Ervens et al., 2014), have observed OH-limited chemistry in the aqueous aerosol phase using GAMMA, and this informed the simpleGAMMA formulation. While transition metal ion chemistry, a possible source of OH (Herrmann et al., 2015), was not included in the first version of GAMMA (McNeill et al., 2012) due to the focus on ammonium sulfate aerosols in that study, these mechanisms may be active in ambient aerosols. Preliminary calculations in GAMMA show that including transition metal ion $\left(\mathrm{Fe}^{+3}\right.$, $\mathrm{Cu}^{+2}, \mathrm{Mn}^{+3}$ ) chemistry following CAPRAM 3.0 (Chemical Aqueous Phase Radical Mechanism; Herrmann et al., 2005) does not perturb the predicted aaSOA yield or product distribution. Aqueous-phase diffusion is not accounted for in GAMMA or simpleGAMMA, that is, Henry's law equilibration is assumed to occur instantaneously and no spatial concentration gradients within the particle are considered. This likely leads to an overestimate of $\mathrm{OH}$ chemistry when this highly reactive species is taken up from the gas phase. However, since we have found that aqueous-phase photochemistry does not dominate aaSOA formation, inclusion of aqueous-phase diffusion limitations in this calculation would not change our results or the formulation of simpleGAMMA. Aqueous-phase diffusion may also be important for relatively large droplets such as those encountered in marine aerosols.

simpleGAMMA is not recommended for the treatment of aqueous SOA formation in cloud water, which is dominated by aqueous-phase photochemistry. The role of UV light in aaSOA formation by glyoxal is unresolved (Galloway et al., 2009, 2011; Volkamer et al., 2009; Kampf et al., 2013). A recent data analysis study using GAMMA (Sumner et al., 2014) suggested a possible role for photo-enhanced chemistry in aaSOA formation by glyoxal involving organic photosensitizers such as fulvic acid (Monge et al., 2012). This chemistry can be represented in simpleGAMMA by including irreversible glyoxal uptake with $\gamma \sim 10^{-3}$ during sunlit hours, consistent with Fu et al. (2008), who based their representation on the experiments of Liggio et al. (2005), and with Waxman et al. (2013). A reactive uptake formulation was also used by Pye et al. (2013) to represent aaSOA formation by IEPOX. While reactive uptake may be the best alternative for representing unknown processes such as glyoxal surface photochemistry, potential issues with reactive uptake formulations stem from the fact that they generally represent two or more physical processes (e.g., reversible uptake of VOCs followed by an aqueous-phase reaction) as one irreversible reactive uptake step. Lin et al. (2014) and Knote et al. (2014) found that a surface reactive uptake formulation for glyoxal led to significantly higher predicted SOA mass than a reversible multiphase representation of the chemistry.

We previously predicted, using GAMMA, that glyoxal is the main contributor to aqueous aerosol-phase "brown carbon" formation by carbonyl-containing VOC precursors (Woo et al., 2013). Following that work, it is straightforward to track the formation of light-absorbing glyoxal derivatives in simpleGAMMA, with concentration-dependent aerosol light absorption calculated in post-processing. However, we note that fast photobleaching of aerosol brown carbon formed via this pathway has been demonstrated, limiting its potential impact on atmospheric chemistry and climate (Sareen et al., 2013; Woo et al., 2013; Lee et al., 2014).

\section{Code availability}

For more information and to access the simpleGAMMA program, please visit mcneill-lab.org/gamma or contact V. Faye McNeill (vfm2103@columbia.edu). simpleGAMMA was originally written in MATLAB (MathWorks, Inc.) and is also available in Fortran. 
Acknowledgements. The authors acknowledge Columbia University for financial support and Shantanu Jathar and Havala Pye for helpful discussions. The authors are also grateful to the anonymous reviewers for their constructive comments and suggestions.

Edited by: A. Archibald

\section{References}

Blando, J. D. and Turpin, B. J.: Secondary organic aerosol formation in cloud and fog droplets: a literature evaluation of plausibility, Atmos. Environ., 34, 1623-1632, doi:10.1016/S13522310(99)00392-1, 2000.

Budisulistiorini, S. H., Li, X., Bairai, S. T., Renfro, J., Liu, Y., Liu, Y. J., McKinney, K. A., Martin, S. T., McNeill, V. F., Pye, H. O. T., Nenes, A., Neff, M. E., Stone, E. A., Mueller, S., Knote, C., Shaw, S. L., Zhang, Z., Gold, A., and Surratt, J. D.: Examining the effects of anthropogenic emissions on isoprene-derived secondary organic aerosol formation during the 2013 Southern Oxidant and Aerosol Study (SOAS) at the Look Rock, Tennessee, ground site, Atmos. Chem. Phys. Discuss., 15, 73657417, doi:10.5194/acpd-15-7365-2015, 2015.

Carlton, A. G., Turpin, B. J., Altieri, K. E., Seitzinger, S. P., Mathur, R., Roselle, S. J., and Weber, R. J.: CMAQ Model Performance Enhanced When In-Cloud Secondary Organic Aerosol is Included: Comparisons of Organic Carbon Predictions with Measurements, Environ. Sci. Technol., 42, 87988802, doi:10.1021/es801192n, 2008.

Eddingsaas, N. C., VanderVelde, D. G., and Wennberg, P. O.: Kinetics and products of the acid-catalyzed ring-opening of atmospherically relevant butyl epoxy alcohols, J. Phys. Chem. A, 114, 8106-8113, doi:10.1021/jp103907c, 2010.

Ervens, B., Turpin, B. J., and Weber, R. J.: Secondary organic aerosol formation in cloud droplets and aqueous particles (aqSOA): a review of laboratory, field and model studies, Atmos. Chem. Phys., 11, 11069-11102, doi:10.5194/acp-1111069-2011, 2011.

Ervens, B., Sorooshian, A., Lim, Y. B., and Turpin, B. J.: Key parameters controlling $\mathrm{OH}$-initiated formation of secondary organic aerosol in the aqueous phase (aqSOA), J. Geophys. Res.Atmos., 119, 3997-4016, doi:10.1002/2013JD021021, 2014.

Fu, T., Jacob, D. J., Wittrock, F., Burrows, J. P., Vrekoussis, M., and Henze, D. K.: Global budgets of atmospheric glyoxal and methylglyoxal, and implications for formation of secondary organic aerosols, J. Geophys. Res., 113, 1-17, doi:10.1029/2007JD009505, 2008.

Galloway, M. M., Chhabra, P. S., Chan, A. W. H., Surratt, J. D., Flagan, R. C., Seinfeld, J. H., and Keutsch, F. N.: Glyoxal uptake on ammonium sulphate seed aerosol: reaction products and reversibility of uptake under dark and irradiated conditions, Atmos. Chem. Phys., 9, 3331-3345, doi:10.5194/acp-9-3331-2009, 2009.

Galloway, M. M., Loza, C. L., Chhabra, P. S., Chan, A. W. H., Yee, L. D., Seinfeld, J. H., and Keutsch, F. N.: Analysis of photochemical and dark glyoxal uptake: Implications for SOA formation, Geophys. Res. Lett., 38, 1-5, doi:10.1029/2011GL048514, 2011.
Gaston, C. J., Riedel, T. P., Zhang, Z., Gold, A., Surratt, J. D., and Thornton, J. A.: Reactive Uptake of an Isoprene-derived Epoxydiol to Submicron Aerosol Particles, Environ. Sci. Technol., 48, 11178-11186, doi:10.1021/es5034266, 2014.

Hallquist, M., Wenger, J. C., Baltensperger, U., Rudich, Y., Simpson, D., Claeys, M., Dommen, J., Donahue, N. M., George, C., Goldstein, A. H., Hamilton, J. F., Herrmann, H., Hoffmann, T., Iinuma, Y., Jang, M., Jenkin, M. E., Jimenez, J. L., Kiendler-Scharr, A., Maenhaut, W., McFiggans, G., Mentel, Th. F., Monod, A., Prévôt, A. S. H., Seinfeld, J. H., Surratt, J. D., Szmigielski, R., and Wildt, J.: The formation, properties and impact of secondary organic aerosol: current and emerging issues, Atmos. Chem. Phys., 9, 5155-5236, doi:10.5194/acp-9-51552009, 2009.

Heald, C. L., Jacob, D. J., Park, R. J., Russell, L. M., Huebert, B. J., Seinfeld, J. H., Liao, H., and Weber, R. J.: A large organic aerosol source in the free troposphere missing from current models, Geophys. Res. Lett., 32, 2-5, doi:10.1029/2005GL023831, 2005.

Herrmann, H., Tilgner, A., Barzaghi, P., Majdik, Z., Gligorovski, S., Poulain, L., and Monod, A.: Towards a more detailed description of tropospheric aqueous phase organic chemistry: CAPRAM 3.0, Atmos. Environ., 39, 4351-4363, doi:10.1016/j.atmosenv.2005.02.016, 2005.

Herrmann, H., Schaefer, T., Tilgner, A., Styler, S. A., Weller, C., Teich, M., and Otto, T.: Tropospheric Aqueous-Phase Chemistry: Kinetics, Mechanisms, and Its Coupling to a Changing Gas Phase, Chem. Rev., 115, 4259-4334, doi:10.1021/cr500447k, 2015.

Hodzic, A., Jimenez, J. L., Madronich, S., Canagaratna, M. R., DeCarlo, P. F., Kleinman, L., and Fast, J.: Modeling organic aerosols in a megacity: potential contribution of semi-volatile and intermediate volatility primary organic compounds to secondary organic aerosol formation, Atmos. Chem. Phys., 10, 5491-5514, doi:10.5194/acp-10-5491-2010, 2010.

Jathar, S. H., Cappa, C. D., McNeill, V. F., and Kleeman, M. J.: Examining New Pathways of Secondary Organic Aerosol Formation in a 3D Model: Role of Absorbed Water, Multi-generational Aging, Intermediate-Volatility Organics and Aqueous Chemistry, in AAAR Annual Meeting, p. 379, 2014.

Jimenez, J. L., Jayne, J. T., Shi, Q., Kolb, C. E., Worsnop, D. R., Yourshaw, I., Seinfeld, J. H., Flagan, R. C., Zhang, X., Smith, K. A., Morris, J. W., and Davidovits, P.: Ambient aerosol sampling using the Aerodyne Aerosol Mass Spectrometer, J. Geophys. Res., 108, 8425, doi:10.1029/2001JD001213, 2003.

Jimenez, J. L., Canagaratna, M. R., Donahue, N. M., Prevot, A. S. H., Zhang, Q., Kroll, J. H., DeCarlo, P. F., Allan, J. D., Coe, H., Ng, N. L., Aiken, A. C., Docherty, K. S., Ulbrich, I. M., Grieshop, A. P., Robinson, A. L., Duplissy, J., Smith, J. D., Wilson, K. R., Lanz, V. A., Hueglin, C., Sun, Y. L., Tian, J., Laaksonen, A., Raatikainen, T., Rautiainen, J., Vaattovaara, P., Ehn, M., Kulmala, M., Tomlinson, J. M., Collins, D. R., Cubison, M. J., Dunlea, E. J., Huffman, J. A., Onasch, T. B., Alfarra, M. R., Williams, P. I., Bower, K., Kondo, Y., Schneider, J., Drewnick, F., Borrmann, S., Weimer, S., Demerjian, K., Salcedo, D., Cottrell, L., Griffin, R., Takami, A., Miyoshi, T., Hatakeyama, S., Shimono, A., Sun, J. Y., Zhang, Y. M., Dzepina, K., Kimmel, J. R., Sueper, D., Jayne, J. T., Herndon, S. C., Trimborn, A. M., Williams, L. R., Wood, E. C., Middlebrook, A. M., 
Kolb, C. E., Baltensperger, U., and Worsnop, D. R.: Evolution of organic aerosols in the atmosphere, Science, 326, 1525-1529, doi:10.1126/science.1180353, 2009.

Kampf, C. J., Waxman, E. M., Slowik, J. G., Dommen, J., Pfaffenberger, L., Praplan, A. P., Prévôt, A. S. H., Baltensperger, U., Hoffmann, T., and Volkamer, R.: Effective Henry's Law Partitioning and the Salting Constant of Glyoxal in Aerosols Containing Sulfate, Environ. Sci. Technol., 47, 4236-4244, doi:10.1021/es400083d, 2013.

Kanakidou, M., Seinfeld, J. H., Pandis, S. N., Barnes, I., Dentener, F. J., Facchini, M. C., Van Dingenen, R., Ervens, B., Nenes, A., Nielsen, C. J., Swietlicki, E., Putaud, J. P., Balkanski, Y., Fuzzi, S., Horth, J., Moortgat, G. K., Winterhalter, R., Myhre, C. E. L., Tsigaridis, K., Vignati, E., Stephanou, E. G., and Wilson, J.: Organic aerosol and global climate modelling: a review, Atmos. Chem. Phys., 5, 1053-1123, doi:10.5194/acp-5-1053-2005, 2005.

Knote, C., Hodzic, A., Jimenez, J. L., Volkamer, R., Orlando, J. J., Baidar, S., Brioude, J., Fast, J., Gentner, D. R., Goldstein, A. H., Hayes, P. L., Knighton, W. B., Oetjen, H., Setyan, A., Stark, H., Thalman, R., Tyndall, G., Washenfelder, R., Waxman, E., and Zhang, Q.: Simulation of semi-explicit mechanisms of SOA formation from glyoxal in aerosol in a 3-D model, Atmos. Chem. Phys., 14, 6213-6239, doi:10.5194/acp-14-6213-2014, 2014.

Kroll, J. H., Ng, N. L., Murphy, S. M., Varutbangkul, V., Flagan, R. C., and Seinfeld, J. H.: Chamber studies of secondary organic aerosol growth by reactive uptake of simple carbonyl compounds, J. Geophys. Res., 110, 1-10, doi:10.1029/2005JD006004, 2005.

Lee, H. J. J., Aiona, P., Laskin, A., Laskin, J., and Nizkorodov, S. A.: Effect of Solar Radiation on the Optical Properties and Molecular Composition of Laboratory Proxies of Atmospheric Brown Carbon, Environ. Sci. Technol., 48, 1021710226, doi:10.1021/es502515r, 2014.

Liggio, J., Li, S.-M., and McLaren, R.: Heterogeneous reactions of glyoxal on particulate matter: identification of acetals and sulfate esters, Environ. Sci. Technol., 39, 1532-1541, 2005.

Lin, G., Sillman, S., Penner, J. E., and Ito, A.: Global modeling of SOA: the use of different mechanisms for aqueous-phase formation, Atmos. Chem. Phys., 14, 5451-5475, doi:10.5194/acp-145451-2014, 2014.

Lin, Y.-H., Zhang, H., Pye, H. O. T., Zhang, Z., Marth, W. J., Park, S., Arashiro, M., Cui, T., Budisulistiorini, S. H., Sexton, K. G., Vizuete, W., Xie, Y., Luecken, D. J., Piletic, I. R., Edney, E. O., Bartolotti, L. J., Gold, A., Surratt, J. D., and Ivan, R.: Epoxide as a precursor to secondary organic aerosol formation from isoprene photooxidation in the presence of nitrogen oxides, P. Natl. Acad. Sci. USA, 110, 6718-6723, doi:10.1073/pnas.1221150110, 2013.

Liu, J., Horowitz, L. W., Fan, S., Carlton, A. G., and Levy, H.: Global in-cloud production of secondary organic aerosols: Implementation of a detailed chemical mechanism in the GFDL atmospheric model AM3, J. Geophys. Res., 117, D15303, doi:10.1029/2012JD017838, 2012.

McNeill, V. F., Woo, J. L., Kim, D. D., Schwier, A. N., Wannell, N. J., Sumner, A. J., and Barakat, J. M.: Aqueous-phase secondary organic aerosol and organosulfate formation in atmospheric aerosols: a modeling study, Environ. Sci. Technol., 46, 8075-8081, doi:10.1021/es3002986, 2012.
Monge, M. E., Rosenørn, T., Favez, O., Müller, M., Adler, G., Abo Riziq, A., Rudich, Y., Herrmann, H., George, C., and D'Anna, B.: Alternative pathway for atmospheric particles growth, P. Natl. Acad. Sci. USA, 109, 6840-6844, doi:10.1073/pnas.1120593109, 2012.

Myriokefalitakis, S., Tsigaridis, K., Mihalopoulos, N., Sciare, J., Nenes, A., Kawamura, K., Segers, A., and Kanakidou, M.: Incloud oxalate formation in the global troposphere: a 3-D modeling study, Atmos. Chem. Phys., 11, 5761-5782, doi:10.5194/acp11-5761-2011, 2011.

Nguyen, T. B., Coggon, M. M., Bates, K. H., Zhang, X., Schwantes, R. H., Schilling, K. A., Loza, C. L., Flagan, R. C., Wennberg, P. O., and Seinfeld, J. H.: Organic aerosol formation from the reactive uptake of isoprene epoxydiols (IEPOX) onto nonacidified inorganic seeds, Atmos. Chem. Phys., 14, 3497-3510, doi:10.5194/acp-14-3497-2014, 2014.

Paulot, F., Crounse, J. D., Kjaergaard, H. G., Kürten, A., St Clair, J. M., Seinfeld, J. H., and Wennberg, P. O.: Unexpected epoxide formation in the gas-phase photooxidation of isoprene, Science, 325, 730-733, doi:10.1126/science.1172910, 2009.

Piletic, I. R., Edney, E. O., and Bartolotti, L. J.: A computational study of acid catalyzed aerosol reactions of atmospherically relevant epoxides, Phys. Chem. Chem. Phys., 15, 18065-18076, doi:10.1039/c3cp52851k, 2013.

Pye, H. O. T., Pinder, R. W., Piletic, I. R., Xie, Y., Capps, S. L., Lin, Y.-H., Surratt, J. D., Zhang, Z., Gold, A., Luecken, D. J., Hutzell, W. T., Jaoui, M., Offenberg, J. H., Kleindienst, T. E., Lewandowski, M., and Edney, E. O.: Epoxide pathways improve model predictions of isoprene markers and reveal key role of acidity in aerosol formation, Environ. Sci. Technol., 47, 1105611064, doi:10.1021/es402106h, 2013.

Sareen, N., Moussa, S. G., and McNeill, V. F.: Photochemical Aging of Light-Absorbing Secondary Organic Aerosol Material, J. Phys. Chem. A, 117, 2987-2996, 2013.

Schwartz, S. E.: Mass-transport considerations pertinent to aqueous phase reactions of gases in liquid-water clouds, in NATO ASI Series, Vol. G6, edited by: Jaeschke, W., 425-471, Springer-Verlag, Berlin Heidelberg, 1986.

Sumner, A., Woo, J. L.-M., and McNeill, V. F.: Model Analysis of Secondary Organic Aerosol Formation by Glyoxal in Laboratory Studies: The Case for Photoenhanced Chemistry, Environ. Sci. Technol., 48, 11919-11925, doi:10.1021/es502020j, 2014.

Surratt, J. D., Chan, A. W. H., Eddingsaas, N. C., Chan, M., Loza, C. L., Kwan, A. J., Hersey, S. P., Flagan, R. C., Wennberg, P. O., and Seinfeld, J. H.: Reactive intermediates revealed in secondary organic aerosol formation from isoprene, P. Natl. Acad. Sci. USA, 107, 6640-6645, doi:10.1073/pnas.0911114107, 2010.

Tanner, R. L., Olszyna, K. J., Edgerton, E. S., Knipping, E., and Shaw, S. L.: Searching for evidence of acid-catalyzed enhancement of secondary organic aerosol formation using ambient aerosol data, Atmos. Environ., 43, 3440-3444, doi:10.1016/j.atmosenv.2009.03.045, 2009.

Volkamer, R., Ziemann, P. J., and Molina, M. J.: Secondary Organic Aerosol Formation from Acetylene $\left(\mathrm{C}_{2} \mathrm{H}_{2}\right)$ : seed effect on SOA yields due to organic photochemistry in the aerosol aqueous phase, Atmos. Chem. Phys., 9, 1907-1928, doi:10.5194/acp9-1907-2009, 2009. 
Waxman, E. M., Dzepina, K., Ervens, B., Lee-Taylor, J., Aumont, B., Jimenez, J. L., Madronich, S., and Volkamer, R.: Secondary organic aerosol formation from semi- and intermediate- volatility organic compounds and glyoxal?: Relevance of $\mathrm{O} / \mathrm{C}$ as a tracer for aqueous multiphase chemistry, Geophys. Res. Lett., 40, 1-5, doi:10.1002/GRL.50203, 2013.

Whipple, E. B.: Structure of glyoxal in water, J. Am. Chem. Soc., 92, 7183-7186, doi:10.1021/ja00727a027, 1970.
Whitby, K.: The physical characteristics of sulfur aerosols, Atmos. Environ., 12, 135-159, doi:10.1016/j.atmosenv.2007.10.057, 1978.

Woo, J. L., Kim, D. D., Schwier, A. N., Li, R., and McNeill, V. F.: Aqueous aerosol SOA formation: Impact on aerosol physical properties, Faraday Discuss., 165, 357-367, doi:10.1039/c3fd00032j, 2013. 